2007 110: 3926-3935

Prepublished online Jul 13, 2007;

doi:10.1182/blood-2007-01-065482

\title{
Rapidly induced, T-cellindependent xenoantibody production is mediated by marginal zone B cells and requires help from NK cells
}

Shengqiao Li, Yehong Yan, Yuan Lin, Dominique M. Bullens, Omer Rutgeerts, Jozef Goebels, Constant Segers, Louis Boon, Ahmad Kasran, Rita De Vos, Christiane Dewolf-Peeters, Mark Waer and An D. Billiau

Updated information and services can be found at:

http://bloodjournal.hematologylibrary.org/cgi/content/full/110/12/3926

Articles on similar topics may be found in the following Blood collections:

Transplantation (1230 articles)

Immunobiology (3314 articles)

Information about reproducing this article in parts or in its entirety may be found online at:

http://bloodjournal.hematologylibrary.org/misc/rights.dtl\#repub_requests

Information about ordering reprints may be found online at:

http://bloodjournal.hematologylibrary.org/misc/rights.dtl\#reprints

Information about subscriptions and ASH membership may be found online at:

http://bloodjournal.hematologylibrary.org/subscriptions/index.dtl

Blood (print ISSN 0006-4971, online ISSN 1528-0020), is published semimonthly by the American Society of Hematology, $1900 \mathrm{M} \mathrm{St}$, NW, Suite 200, Washington DC 20036.

Copyright 2007 by The American Society of Hematology; all rights reserved.

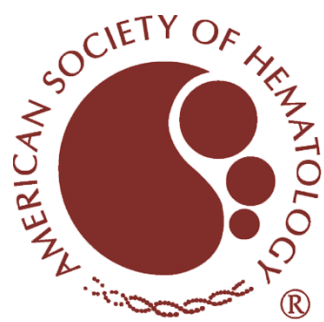




\title{
Rapidly induced, T-cell-independent xenoantibody production is mediated by marginal zone B cells and requires help from NK cells
}

\author{
Shengqiao Li, ${ }^{1}$ Yehong Yan, ${ }^{1}$ Yuan Lin, ${ }^{1}$ Dominique M. Bullens, ${ }^{2}$ Omer Rutgeerts, ${ }^{1}$ Jozef Goebels, ${ }^{1}$ Constant Segers, ${ }^{1}$ \\ Louis Boon, ${ }^{3}$ Ahmad Kasran, ${ }^{2}$ Rita De Vos, ${ }^{4}$ Christiane Dewolf-Peeters, ${ }^{4}$ Mark Waer, ${ }^{1}$ and An D. Billiau ${ }^{1}$ \\ ${ }^{1}$ Laboratory of Experimental Transplantation and ${ }^{2}$ Laboratory of Experimental Immunology, University of Leuven, Leuven, Belgium; ${ }^{3}$ Bioceros, Utrecht, \\ the Netherlands; and ${ }^{4}$ Morphology and Molecular Pathology, University of Leuven, Leuven, Belgium
}

\begin{abstract}
Xenoantibody production directed at a wide variety of $\mathrm{T}$ lymphocyte-dependent and T lymphocyte-independent xenoantigens remains the major immunologic obstacle for successful xenotransplantation. The B lymphocyte subpopulations and their helper factors, involved in T-cellindependent xenoantibody production are only partially understood, and their identi-
\end{abstract}

fication will contribute to the clinical applicability of xenotransplantation. Here we show, using models involving T-celldeficient athymic recipient mice, that rapidly induced, T-cell-independent xenoantibody production is mediated by marginal zone B lymphocytes and requires help from natural killer (NK) cells. This collaboration neither required NK-cell-mediated
IFN- $\gamma$ production, nor NK-cell-mediated cytolytic killing of xenogeneic target cells. The T-cell-independent IgM xenoantibody response could be partially suppressed by CD40L blockade. (Blood. 2007; 110:3926-3935)

() 2007 by The American Society of Hematology

\section{Introduction}

Successful xenotransplantation may alleviate the ever-increasing need for donor organs, but severe immunologic barriers, of which xenoreactive antibodies represent the most important 1, still hamper (pre)clinical application. Pigs are now generally considered the most suitable organ donors for clinical xenotransplantation, ${ }^{1}$ but transplantation of pig organs into nonhuman primates, currently constituting the best validated preclinical model, leads to xenograft rejection within a few hours. This hyperacute rejection is mediated by pre-existing, so-called "natural antibodies," which are directed at a specific Gal $\alpha 1,3 \mathrm{Gal} \beta 1,4 \mathrm{GlcNAc}$ (Gal) oligosaccharide, that is present on (especially endothelial) proteins of most lower animal species, but not of nonhuman primates or man..$^{2-4}$ Anti-Gal natural antibodies can rapidly activate the complement system of the recipient, leading to hyperacute rejection. ${ }^{5}$ Several procedures have been explored in recent years to solve the problem of hyperacute rejection. ${ }^{6,7}$ The most appealing ones were the development of genetically modified donor pig strains that either expressed transgenes of human complement regulatory proteins, able to interfere with complement activation, ${ }^{8}$ or that lacked the $\alpha 1,3$-galactosyltransferase gene to synthesise $\alpha \mathrm{Gal}$. $^{9,10}$ The latter pig strain seemed particularly attractive, as Gal antigens had been found to be also strongly involved in acute vascular xenograft rejection, a second type of xenograft rejection that develops within a few days in situations where hyperacute rejection is prevented. ${ }^{7,11}$ It was hoped, therefore, that elimination of Gal epitopes would prevent both hyperacute rejection and acute vascular rejection.

A number of recent reports on the transplantation of $\alpha 1,3$ galactosyltransferase-ko pig kidney or heart grafts in nonhuman primates have shown that loss of Gal expression in donor pig organs could indeed prevent hyperacute rejection, but that T-cell- dependent IgG xenoantibodies were induced against non-Gal xenoantigens, unless a treatment regimen was used that resulted in specific T-cell xenotolerance. ${ }^{12-14}$ In the latter case, long-term functional renal xenograft survival was obtained, but after a few months, mild focal thrombotic microangiopathy was observed, suggesting that additional modifications to the treatment regimen are needed to permit the development of the kind of long-term survival required for clinical applications. ${ }^{13}$ Although nonimmune factors such as incompatibilities between pig endothelial cells and the primate coagulation system may play a role in the occurrence of microangiopathy and/or loss of $\alpha 1,3$-galactosyltransferase-ko organs, involvement of T-cell-independent anti-non-Gal immune xenoreactivity cannot be excluded. Anti-Gal xenoantibodyproducing B cells were recently described as $\mathrm{Mac1}^{-} \mathrm{B} 1 \mathrm{~b}-\mathrm{like}$ splenic B cells. ${ }^{15}$ In contrast, T-cell-independent anti-non-Gal xenoantibody formation, which may contribute to residual xenoreactivity in these mentioned studies, ${ }^{12-14}$ is as yet poorly understood. Here, we challenged T-cell-deficient athymic mice with hamster heart xenografts or xenoantigens, a combination that does not involve Gal expression incompatibility, and report that rapidly induced anti-non-Gal xenoantibody production was mediated by marginal zone B (MZB) cells and required help from natural killer (NK) cells.

\section{Materials and methods}

\section{Animals}

T-cell-deficient nude C57BL/6 H- $2^{\mathrm{b}}$ and BALB/c H- $2^{\mathrm{d}}$ male mice, 8 to 10 weeks old, purchased from M\&B (DK-8680; Ry, Denmark) were
Submitted January 2, 2007; accepted July 4, 2007. Prepublished online as Blood First Edition paper, July 13, 2007; DOI 10.1182/blood-2007-01-065482.

An Inside Blood analysis of this article appears at the front of this issue.

The online version of this article contains a data supplement.
The publication costs of this article were defrayed in part by page charge payment. Therefore, and solely to indicate this fact, this article is hereby marked "advertisement" in accordance with 18 USC section 1734.

(C) 2007 by The American Society of Hematology 
used as recipients. The functional T-cell deficiency of these mice was confirmed at regular intervals by verifying their inability to reject allogeneic heart or skin grafts. Inbred golden hamsters (AU/Hö Han Rj), purchased from the Center d'Elevage R. Janvier (Le Genest-St-Isle, France), were used as donors. IFN- $\gamma^{-1-}$ and TCR $\beta^{-1-}$ C57BL/6 mice were purchased from the Jackson Laboratory (Bar Harbor, ME). CB17SCID mice were kindly provided by D. Schols (Rega Institute, University of Leuven, Leuven, Belgium). Nude mice were kept in a specific pathogen-free facility. All experiments were approved by the Ethics Committee on Research Animal Care of the University of Leuven.

\section{Surgical procedures}

Heterotopic xenoheart transplantation was performed as previously described. ${ }^{16}$ Grafts were implanted in the recipient neck and graft beating was checked daily, either by inspection or palpation. Cessation of beating indicated xenograft rejection, which was confirmed by histologic examination.

For splenic tissue transplantations, $1-\mathrm{mm}^{3}$ fragments of spleens from either naive or lethally irradiated donor mice were placed under the kidney capsules of recipient mice via a small subcostal incision. Tissue from 1.5 donor spleens was used for 1 recipient. Alternatively, spleen tissue fragments were stirred in collagenase $(1 \mathrm{mg} / \mathrm{mL})$ at $37^{\circ} \mathrm{C}$ for 1 hour. After filtration, cells were washed twice and counted. Cellular viability of these grafts was more than $95 \%$.

\section{Immunization}

Mice were immunized using $100 \mu \mathrm{g}$ TNP-Ficoll (Biosearch Technologies, Novato, CA) through intravenous injection, or $200 \mu \mathrm{L}$ hamster red blood cells (RBCs) through intravenous injection.

\section{Measurement of serum antibodies}

Mouse anti-TNP-Ficoll serum IgM and IgG2a were determined by flow cytometry, using TNP-Ficoll microbeads (Microbeads Bioscience, Arlington, MA) and FITC-labeled goat-anti-mouse IgM and hamster anti-mouse IgG2a antibodies (Serotec, Kidlington, United Kingdom). Serum mouse anti-hamster $\operatorname{IgM}$ and $\operatorname{IgG}$ were determined as previously described. ${ }^{16}$

\section{In vivo depletion of NKT/NK cells and in vivo blockade of Ly49D and CD40L}

As previously reported, ${ }^{17,18} \mathrm{NK} / \mathrm{NKT}$ cells were depleted by intraperitoneal injection of TM- $\beta 1$ (kindly provided by T. Tanaka, Osaka University, Japan). In vivo blockade of Ly49D receptor was performed by intraperitoneal administration of blocking anti-Ly49D mAb (4E5; Pharmingen, Erembodegem, Belgium) or control rat Ig2a (Serotec), at a dose of $100 \mu \mathrm{g}$, 1 day before hamster RBC immunization or hamster heart transplantation. CD40L blockade was performed by intraperitoneal injection of $300 \mu \mathrm{g}$ of MR1 (anti-CD40L; kindly provided by L.B. and A.K.), or control hamster $\mathrm{IgG}$ (Biotrend, Keulen, Germany) on days $-1,0,1,3$, and 5 relative to the day of hamster RBC immunization.

\section{Monoclonal antibodies and flow cytometry}

Flow cytometric analysis of peripheral blood mononuclear cells and splenocytes was performed as described previously. ${ }^{16}$ Antibodies used were as follows: FITC-, PE-, or PerCP-conjugated anti-mouse $\mathrm{H} 2 \mathrm{~Kb}, \mathrm{CD} 3 \mathrm{e}$, F4/80, CD11b, CD21/CD35, CD5, NK 1.1, DX5, CD45R/B220, Ly-G6, Ly49D, and CD23, all purchased from BD Biosciences Pharmingen (Erembodegem, Belgium); PE-conjugated goat anti-mouse IgM (Cedarlane, Burlington, ON) and FITC-conjugated rat anti-mouse IgD (Southern Biotechnology, Birmingham, AL).

\section{Cell isolation procedures}

Magnetic-activated cell sorting (MACS) was used to isolate $\mathrm{NK}_{1.1}^{+}$, $\mathrm{CD} 19^{+}$, and $\mathrm{DX}^{+}$cells from spleens. In brief, a single-cell suspension depleted from RBCs and debris was incubated either with purified anti-mouse NK1.1 (IgG2a; BD Pharmingen) followed by anti-mouse $\mathrm{IgG} 2 \mathrm{a}+\mathrm{b}$ microbeads (Miltenyi Biotec, Munchen Gladbach, Germany) each for 15 minutes at $4^{\circ} \mathrm{C}$, or with anti-mouse DX5 or anti-mouse CD19 microbeads (Miltenyi Biotec) for 20 minutes at $4^{\circ} \mathrm{C}$. Magnetic separation was subsequently performed using the LS column (Miltenyi Biotec). The purity of selected cell population was more than $95 \%$.

For isolation of MZB and B1b cells, CD19+ MACS-isolated cells were stained with anti-CD21/CD35(CR2/CR1)-FITC and anti-CD23(FceRII)-PE (eBioscience, Halle, Belgium) and resuspended in PBS at a concentration of $3 \times 10^{6}$ cells $/ \mathrm{mL}$. On a FACSVantage (Becton Dickinson, San Jose, CA), $\mathrm{CD} 21^{\text {neg }} \mathrm{CD} 23^{\text {neg }} \mathrm{B} 1 \mathrm{~b}$ and $\mathrm{CD} 21^{\text {high }} \mathrm{CD} 23^{\text {low }} \mathrm{MZB}$ cells were sorted, ${ }^{15,19}$ collected, and resuspended in PBS for intravenous injection. Purity of selected cell populations was more than $90 \%$.

\section{NK cytotoxicity assay}

NK cytotoxicity was tested using either purified NK1.1 $1^{+}$cells or DX5 $5^{+}$ cells or nylon wool-enriched NK cells using the standard ${ }^{51} \mathrm{Cr}$-release assay, as described previously. ${ }^{20}$

\section{Light microscopy, immunohistochemistry, and electron microscopy}

For routine microscopic examination, spleens or grafted hearts were formalin fixed and stained with hematoxylin and eosin (HE). For immunohistochemistry, tissues were snap-frozen in liquid nitrogen and kept at $-70^{\circ} \mathrm{C}$ until use. Cryostat sections of $4 \mu \mathrm{m}$ were air-dried overnight at room temperature and fixed in acetone. Next, endogenous peroxidase activity was blocked by adding $0.3 \% \mathrm{H}_{2} \mathrm{O}_{2}$, and nonspecific staining was blocked by incubation with $5 \%$ normal rabbit or goat serum. Sections were incubated with the following mAbs: rat antimouse CD21/CD35, FDC-M1, CD3e, DX5, C3, and P-selectin; hamster anti-mouse CD120a; biotinylated rat anti-mouse CD45R/B220, syndecan 1 (CD138), or CD5 (all from BD Pharmingen); rat anti-mouse CD169 (sialoadhesin; ImmunoKontact, Abingdon, United Kingdom); goat anti-mouse IgM (Serotec) and $\operatorname{IgD}$ (Southern Biotechnology); biotinylated MOMA-1 (ImmunoKontact); and biotinylated F4/80 (Serotec). Where unconjugated mAbs were used, sections were subsequently incubated with biotinlyated rabbit anti-rat or anti-goat Ig mAb (DAKO, Merelbeke, Belgium). Finally, sections were incubated in horseradish peroxidase (HRP)-conjugated avidin-biotin complex (ABC), positive staining was visualized using DBA and/or substrate-chromogen solution (DAKO, Carpinteria, CA), and sections were counterstained with Mayer hematoxylin. Microscopic analysis was performed with a Zeiss Axioplan2 microscope (Zeiss, Gottingen, Germany) and Carl Zeiss Vision (KS 400V 3.00; Zeiss, Hallbergmoos, Germany). Original magnification $20 \times / 0.50$.

For electron microscopy, small spleen fragments were immediately fixed in $2.5 \%$ glutaraldehyde and $0.1 \mathrm{M}$ phosphate buffer at $4^{\circ} \mathrm{C}$. Postfixation was performed in $1 \%$ osmium tetroxide and $0.1 \mathrm{M}$ phosphate buffer for 1 hour. Next, samples were dehydrated in a graded series of alcohol and embedded in epoxy resin. Ultrathin sections were cut, stained with uranyl acetate and lead citrate, and examined at $50 \mathrm{kV}$ using a Zeiss EM 900 electron microscope (Zeiss, Oberkochen, Germany). Images were recorded digitally with a Jenoptik Progress C14 camera system (Jena, Germany), operated using Image-Pro Express software version 4.0 (Media Cybernetics, Silver Spring, MD).

\section{Statistical analysis}

The Mann-Whitney $U$ test was used to estimate the level of significance of differences between groups of data. A $P$ value less than .05 was considered evidence for a statistically significant difference. 
Table 1. Hamster heart graft survival in C57BL/6 nude mice receiving various treatments

\begin{tabular}{|c|c|c|c|c|}
\hline Group & Recipients & Additional treatment & $\mathbf{n}$ & $\begin{array}{l}\text { Graft survival, } \\
\text { mean } d \pm S D\end{array}$ \\
\hline A & C57BL/6 nude & No & 20 & $5.1 \pm 0.5$ \\
\hline B & C57BL/6 nude & Splenectomy at days $-90,-14,0,2$, and 3 & 24 & No rejection* \\
\hline C & C57BL/6 nude splenectomized & Day-0 transfer of splenocytes from naive syngeneic mice & 6 & No rejection* \\
\hline D & C57BL/6 nude splenectomized & $\begin{array}{l}\text { Day-0 transfer of splenocytes from xenograft-rejecting } \\
\text { syngeneic mice }\end{array}$ & 7 & No rejection* \\
\hline E & C57BL/6 nude splenectomized & Transfer of serum from xenograft-rejecting syngeneic mice & 5 & Hyperacute rejection $\dagger$ \\
\hline $\mathrm{F}$ & C57BL/6 nude & 2 Gy TBI at day -2 & 6 & No rejection* \\
\hline G & C57BL/6 nude & 2 Gy TBI at day -14 & 4 & No rejection* \\
\hline $\mathrm{H}$ & C57BL/6 nude & 2 Gy TBI at day -28 & 4 & $6 \pm 1.3$ \\
\hline
\end{tabular}

${ }^{\star}$ Experiments were terminated at 60 days after hamster heart transplantation.

†Rejection occurred within 1 to 4 hours.

\section{Results}

T-cell-independent xenoantibodies leading to hamster xenograft rejection in C57BL/6 nude mice are produced by MZB cells

C57BL/6 nude mice rejected hamster xenoheart grafts at day 5.1 plus or minus 0.5 (Table 1; group A), with high serum $\operatorname{IgM}$ xenoantibody levels (mean fluorescence intensity [MFI] $36.1 \pm 8.3$ $[\mathrm{n}=6]$; Figure 1A,B) and immunohistochemical signs typical of acute vascular rejection ${ }^{16}$ (IgM and complement deposition and endothelial P-selectin expression; Figure S1, available on the Blood website; see the Supplemental Materials link at the top of the online article). Following splenectomy (on days $-90,-14,0,2$, or 3 relative to xenografting), xenografts survived indefinitely (Table 1; group B), and $\operatorname{IgM}$ xenoantibodies were absent (not shown).
Splenectomized recipients given whole splenocytes from either syngeneic naive (Table 1; group C) or from xenograft-rejecting syngeneic eusplenic animals (Table 1; group D) failed to reject xenohearts. In contrast, transfer of serum, taken from eusplenic C57BL/6 nude mice on day 7 after xenoheart transplantation, to splenectomized recipients bearing a beating hamster heart graft, induced hyperacute rejection (Table 1; group E). These data indicate that xenograft rejection is dependent both on splenocytes and splenic architecture in the induction phase, whereas the effector phase of xenograft rejection can be spleen independent.

Many xenoantigens are T-cell-independent type II antigens. ${ }^{16,21}$ The B-cell populations contributing to T-cell-independent type II antibody production have been reported to consist of both MZB cells in the spleen and B1b lymphocytes. ${ }^{22}$ In view of the effect of splenectomy in our model, we proposed a role for MZB cells, and in order to investigate this, recipient mice were given 2 Gy

A

Serum IgM Xab

C57BI/6 nude hamster RBC

C57BL/6 nude 2 Gy hamster RBC

C57BL/6 nude rejecting xenoheart

Balb/c nude naïve

Balb/c nude hamster RBC

Balb/c nude xenoheart graft

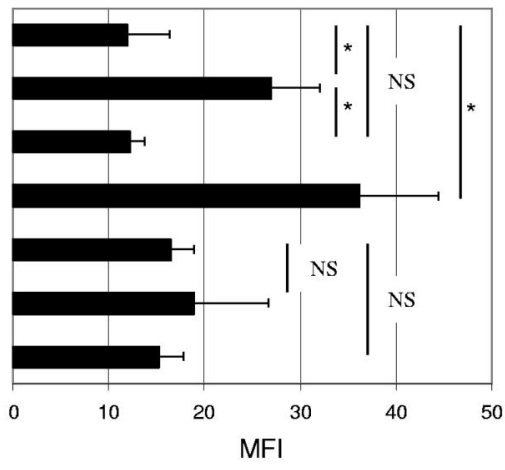

B
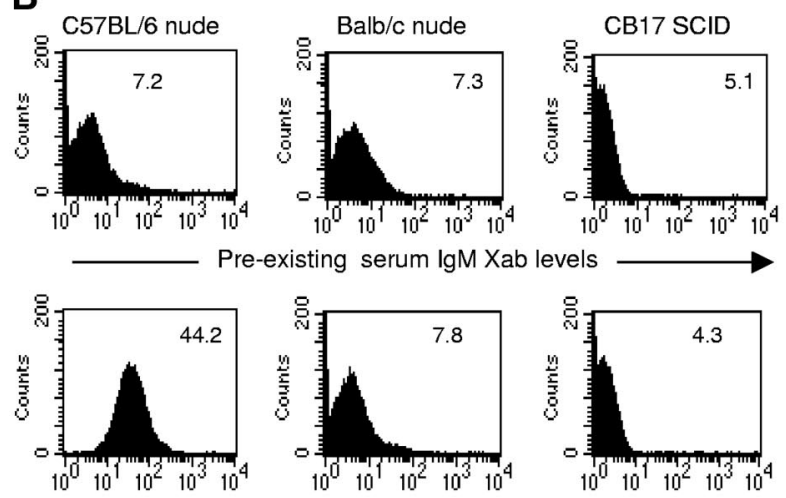

C

CB17 SCID given

Balb/c nude

spleen cells 2

weeks before

immunization

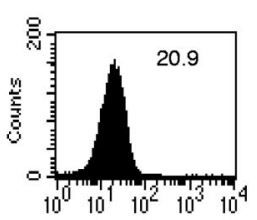

Figure 1. IgM xenoantibody response in C57BL/6 nude, $B A L B / c$ nude, and CB17SCID mice given BALB/c nude splenocytes. (A) Naive nude animals were either immunized with hamster RBCs (C57BL/6, $\mathrm{n}=7$; BALB/c, $\mathrm{n}=3$ ) or given a hamster xenoheart (C57BL/6, $n=7$; BALB/c, $n=6$ ). Serum hamster-specific IgM xenoantibodies were assayed either on day 7 (hamster RBC), or between days 2 and 6 (C57BL/6, at the time of xenograft rejection), or between days 3 and 12 (BALB/c, no rejection of xenografts). One C57BL/6 nude group was given $2 \mathrm{~Gy}$ TBI 1 week before hamster RBC immunization $(n=6)$. Naive BALB/c nude $(n=12)$ and C57BL/6 nude $(n=9)$ animals were used as controls. Bars represent the mean ( \pm SE) MFI values. ${ }^{*} P<.05$; NS indicates not significant for comparison between groups. (B) Histograms illustrating IgM xenoantibody serum levels of naive (top panels) or hamster RBC-immunized (bottom panels) nude C57BL/6, nude BALB/c, or CB17 SCID mice (MFI is indicated in the top right corner). (C) Histogram illustrating IgM xenoantibody serum levels of CB17 SCID mice after transfer of $120 \times 10^{6} \mathrm{BALB} / \mathrm{c}$ nude splenocytes on day -14 . Serum IgM xenoantibodies were determined on day 7 relative to hamster RBC immunization ( 1 of 2 identical experiments is shown). 
Figure 2. Effect of 2 Gy on splenic white pulp and number of splenic MZB cells in C57BL/6 nude mice. (A) Overview of HE and IgM stainings, performed on frozen sections (all pictures taken at the same magnification): spleens from C57BL/6 nude mice before and 1 week and 4 weeks after 2 Gy TBI irradiation. The marginal zones are indicated by asterisks, showing that $\operatorname{lgM}^{+}$ MZB cells disappeared by 1 week after TBI and exhibited partial repopulation by 4 weeks after TBI. See "Light microscopy, immunohhistochemistry, and electron microscopy" for complete image acquisition information. (B) Flow cytometric analysis of splenocytes from C57BL/6 mice before and 1 week or 3 weeks after 2 Gy $\mathrm{TBI}$ irradiation. Results shown were obtained in the $\mathrm{B}_{2} 2 \mathrm{O}^{+}$ lymphocyte gate, MZB cells were identified as CD21 ${ }^{\text {hi }} \mathrm{CD} 23^{\text {lo }}$, follicular B (FO) cells as $C D 21^{10} \mathrm{CD} 23^{\mathrm{hi}}$, and $\mathrm{B} 1 \mathrm{~b}$ cells as CD21 $1^{\text {neg }} C D 23^{\text {neg. }}$.

\author{
A

HE

B

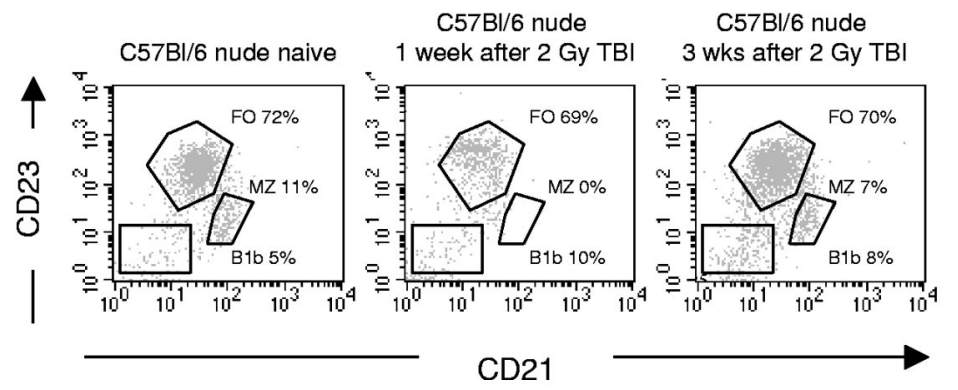

C57BI/6 nude naive

C57BI/6 nude 1 wk after 2 Gy TBI
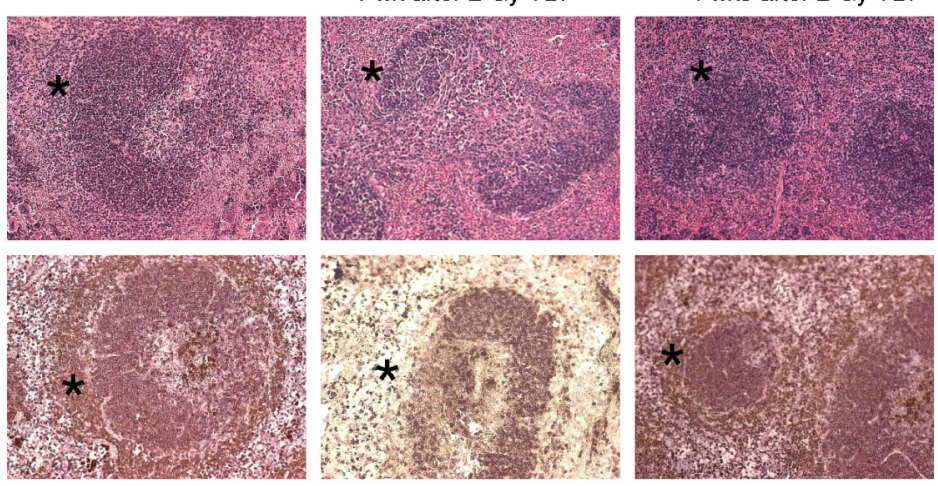

C57BI/6 nude
CD21 total body irradiation (TBI), resulting — as previously reported $^{23,24}$ - in a selective and almost complete, but temporary depletion of MZB cells (confirmed by HE and immunohistochemical stainings, and by flow cytometry; Figure 2). Of note, low-dose TBI had neither an effect on pre-existing natural antibody serum levels nor on the frequency of splenic NK1.1 ${ }^{+}$ cells (not shown). Immunization with hamster RBCs 1 week after TBI in C57BL/6 nude mice failed to result in significant serum IgM xenoantibody levels (MFI $12.2 \pm 1.5[\mathrm{n}=6]$ versus $27 \pm 5$ in nonirradiated immunized [n=7] and $12 \pm 4.4$ in naive [ $\mathrm{n}=9$ ]; Figure 1A). Accordingly, xenografts transplanted on day 2 or 14 were accepted indefinitely (Table 1; groups F,G) without IgM xenoantibody production (not shown). In contrast, xenografting at week 4 after TBI, when MZB cells had recovered, again resulted in acute vascular rejection (Table 1; group $\mathrm{H}$ ) accompanied with high $\operatorname{IgM}$ xenoantibody levels (not shown).
In order to confirm that MZB cells and not B1b lymphocytes were responsible for rapidly induced IgM xenoantibody production, MACS-enriched CD19 ${ }^{+} \mathrm{B}$ cells from BALB/c nude spleens were purified using fluorescence-activated cell sorter (FACS) sorting into $\mathrm{CD} 21^{\text {high }} \mathrm{CD} 23^{\text {low }} \mathrm{MZB}$ cells and $\mathrm{CD} 21^{\text {neg }} \mathrm{CD} 23^{\text {neg }} \mathrm{B} 1 \mathrm{~b}$ cells $^{15,19}$ (Figure 3A). CB17 severe combined immunodeficiency (SCID) mice were given 2 to $5 \times 10^{6}$ subset $\mathrm{B}$ cells intravenously on day 0 , and $200 \mu \mathrm{L}$ whole hamster blood on day 7. Serum IgM xenoantibodies were measured on day 12 (Figure 3B): as expected, unreconstituted SCID mice did not produce $\operatorname{IgM}$ xenoantibodies (mean MFI 1.5 \pm 0.1 SE [individual values 1.4, 1.3, 1.3, 1.8; $\mathrm{n}=4]$ ). CB17SCID mice given $\mathrm{CD} 19^{+} \mathrm{CD} 21^{\text {neg }} \mathrm{CD} 23^{\text {neg }} \mathrm{B} 1 \mathrm{~b}$ cells were equally unable to produce a significant $\operatorname{IgM}$ xenoantibody response (mean MFI 1.7 $\pm 0.2 \mathrm{SE}$ [individual values 1.9, 1.8, 1.4; $\mathrm{n}=3]$ ), whereas in contrast, those given $C D 19^{\text {pos }} \mathrm{CD} 21^{\text {high }} \mathrm{CD} 23^{\text {low }}$ MZB cells produced significantly higher IgM xenoantibody levels (mean MFI $10 \pm$ 1.4 SE [individual values 8.4, 8.8, 12.8; $\mathrm{n}=3$ ];
A

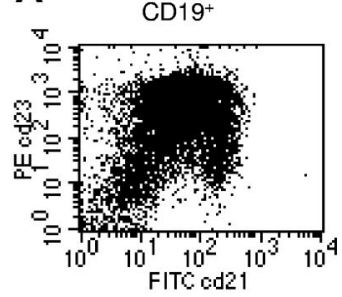

B

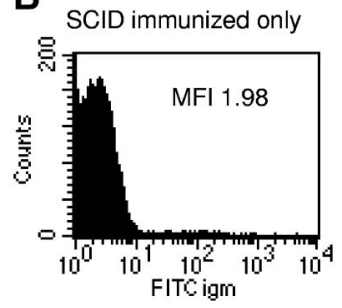

CD21 $1^{\text {hi }} \mathrm{CD} 23^{\text {lo }} \mathrm{MZ}$ B cells

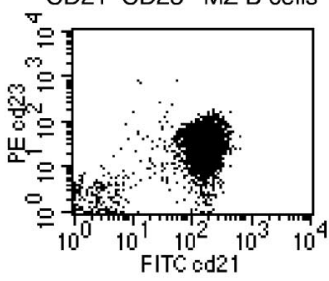

$\mathrm{SCID}+\mathrm{MZB}+$ immunized

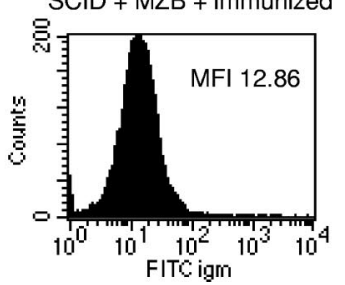

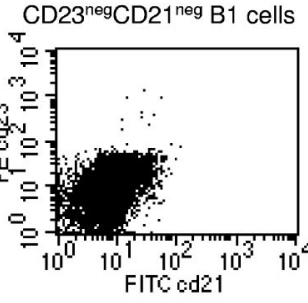

$\mathrm{SCID}+\mathrm{B} 1 \mathrm{~b}+$ immunized

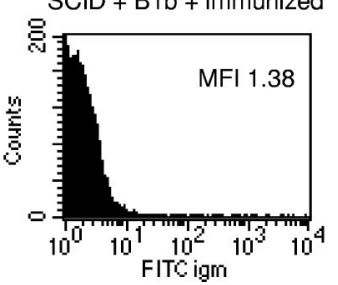

Figure 3. MZB cells, not B1b cells, are responsible for rapidly induced IgM xenoantibody formation. (A) MACS-enriched CD19pos B cells from BALB/C nude spleens (left panel) were purified using FACS sorting into CD21 $1^{\text {high }} C D 23^{\text {low }}$ MZB cells (middle panel) and CD21 ${ }^{\text {neg } C D 23^{\text {neg }}} \mathrm{B} 1 \mathrm{~b}$ cells (right panel). Representative plots are shown from 3 identical experiments. (B) CB17 SCID mice were given 2 to $5 \times 10^{6}$ subset $B$ cells intravenously on day 0 , and $200 \mu \mathrm{L}$ whole hamster blood on day 7. Serum IgM xenoantibody titers in an unreconstituted SCID mouse (left panel), a SCID mouse given CD19pos CD21 $1^{\text {high }}$ CD23 ${ }^{\text {low }}$ MZB cells (middle panel), and a SCID mouse given CD19pos CD2 $1^{\text {neg } C D 23^{\text {neg }}} \mathrm{B} 1 \mathrm{~b}$ cells (right panel). Representative plots are shown from 1 of 3 to 4 mice from 3 identical experiments. 
Table 2. Hamster heart survival in BALB/c nude mice receiving various treatments and in C57BL/6 $\mathrm{TCR}^{-/-}$mice $^{-1}$

\begin{tabular}{|c|c|c|c|c|}
\hline Group & Recipients & Treatment & $\mathbf{n}$ & $\begin{array}{l}\text { Graft survival, } \\
\text { mean } d \pm S D\end{array}$ \\
\hline A & BALB/c nude & No & 8 & $>200 \pm 67.1^{*}$ \\
\hline B & BALB/c nude splenectomized & $\begin{array}{l}\text { Transfer of xenograft-rejecting C57BL/6 nude serum } 2 \text { weeks after } \\
\text { transplantation }\end{array}$ & 4 & Hyperacute rejection $\dagger$ \\
\hline C & BALB/c nude & Transfer of nonirradiated C57BL/6 nude mouse splenic tissue & 8 & 5 of 8 rejected at $6 \mathrm{POD}$ \\
\hline D & BALB/c nude & Transfer of lethally irradiated C57BL/6 nude mouse splenic tissue & 11 & 9 of 11 rejected at 6 POD \\
\hline E & BALB/c nude & Transfer of lethally irradiated BALB/c nude mouse splenic tissue & 5 & No rejectionł \\
\hline $\mathrm{F}$ & BALB/c nude & Transfer of radioresistant C57BL/6 nude mouse splenic cellsł & 6 & 4 of 6 rejected at $6 \mathrm{POD}$ \\
\hline G & BALB/c nude & Transfer of NK1.1 ${ }^{+}$cells§ obtained from C57BL/6 nude mice & 6 & 4 of 6 rejected at $5-6 P O D \|$ \\
\hline $\mathrm{H}$ & BALB/c nude & Transfer of NK1.1- cells§ obtained from C57BL/6 nude mice & 4 & No rejectionף \\
\hline 1 & BALB/c nude & Transfer of NK1.1 $1^{+}$cells obtained from C57BL/6 IFN- $\gamma^{-1-}$ mice & 4 & 3 of 4 rejected at $5-6 \mathrm{POD} \|$ \\
\hline J & C57BL/6 TCR $\beta^{-1-}$ & No & 10 & 8 of 10 rejected at 5-7 POD \\
\hline K & BALB/c nude & Transfer of spleen cells obtained from C57BL/6 TCR $\beta^{-1-}$ mice & 4 & 3 of 4 rejected at day 6-7 \\
\hline
\end{tabular}

POD indicates postoperative day.

*Some recipients were sacrificed for analysis later than day 60 after xenoheart transplantation.

†Rejection occurred within 1 to 4 hours.

†Radioresistant splenic cells obtained from collagenase-treated lethally irradiated C57BL/6 nude mouse spleens (see "Surgical procedures").

$\S$ A total of $6 \times 10^{6}$ cells were transferred.

$\|$ Severe inflammatory lesions occurred in the remaining mice.

ๆExperiments were terminated at 60 days after hamster heart transplantation.

${ }^{* \star} A$ total of $100 \times 10^{6}$ cells were transferred.

$P<.05$ for difference with B1b-transferred mice, Mann-Whitney $U$; Figure 3B).

Despite functional MZB cells, BALB/c nude mice fail to produce IgM xenoantibodies and to reject xenografts

In contrast to $\mathrm{C} 57 \mathrm{BL} / 6$ nude mice, $\mathrm{BALB} / \mathrm{c}$ nude mice permanently accepted hamster heart xenografts (Table 2; group A), showing neither IgM nor complement deposition (Figure S1), and failed to produce significant levels of IgM xenoantibodies following either xenografting (MFI $15.3 \pm 2.4 ; \mathrm{n}=7$ ) or hamster RBC immunization (MFI 18.9 $\pm 7.7[\mathrm{n}=3]$ versus $16.5 \pm 2.5[\mathrm{n}=12]$ in naive; Figure 1A,B). Transfer of serum from xenoheart-rejecting C57BL/6 nude recipients to xenoheart graft-bearing BALB/c nude recipients resulted in hyperacute rejection (Table 2; group $\mathrm{B})$, indicating that the failure of $\mathrm{BALB} / \mathrm{c}$ nude mice to reject heart xenografts was due to their inability to produce sufficient quantities of IgM xenoantibodies. Of note, complement activity (CH50 assay) in $\mathrm{C} 57 \mathrm{BL} / 6$ and $\mathrm{BALB} / \mathrm{c}$ nude mice was found to be identical (not shown).

The marginal zone and B-cell follicles in BALB/c nude mice were similar to those of C57BL/6 nude mice, as evidenced by immunohistochemistry (Figure S2) and flow cytometry for MZBcharacterizing $\operatorname{IgD}^{\text {lo }}, C D 23^{\text {lo }}, \operatorname{IgM}^{\text {hi }}$ and $C D 21^{\text {hi }}$ on splenocytes and peripheral blood lymphocytes (not shown). Moreover, following transfer of BALB/c nude splenocytes into CB17 SCID mice, which did not have pre-existing IgM xenoantibodies (MFI 5.1, 5.9 $[\mathrm{n}=2]$; Figure 1C) and which were unable to generate an $\operatorname{IgM}$ xenoantibody response by themselves (MFI 2.9, 4.3; $\mathrm{n}=2$ ), hamster RBC immunization gave rise to high IgM xenoantibody levels (MFI 33.2, 20.9; $\mathrm{n}=2$ ), suggesting that BALB/c nude mice have a functioning MZB-cell compartment, but lack "help" signals required for IgM xenoantibody production. In order to identify this helper factor, 7 days prior to xenografting, BALB/c nude recipients were given under the kidney capsule either spleen tissue from untreated C57BL/6 nude mice, or spleen tissue from 8-Gy TBItreated C57BL/6 nude mice (leading to depletion of splenic B cells, as confirmed by immunohistochemistry; not shown), or were given radioresistant C57BL/6 nude splenocytes obtained by collagenase digestion of 8-Gy TBI-irradiated C57BL/6 spleens. In most cases, in each group (5 of 8, 9 of 11, and 4 of 6, respectively; Table 2; groups C-F), acute vascular rejection developed with increased IgM xenoantibody levels (not shown). Appropriate control experiments confirmed that, under these experimental conditions, the $\mathrm{B}$ cells responsible for $\operatorname{IgM}$ xenoantibody production and acute vascular rejection were exclusively contained within the BALB/c nude recipient MZB-cell compartment (Table S1). Also, splenic tissue grafts from 8-Gy TBI-treated BALB/c nude mice did not restore the ability for $\operatorname{IgM}$ xenoantibody production and xenograft rejection (Table 2; group E), ruling out a strain-independent, irradiation-induced effect. These data indicated that functionally intact MZB cells in BALB/c nude mice lacked "help" that could be delivered by CB17 SCID mice or by radioresistant C57BL/6 nude splenocytes.

\section{NK1.1 $1^{+}$-cell help is required for T-independent IgM xenoantibody production and is defective in BALB/c nude mice}

Phenotyping of collagenase-treated, lethally irradiated C57BL/6 nude spleen cells, as used in the aforementioned transfer experiments, showed that $50 \%$ of cells expressed NK1.1 (not shown). In addition, in vivo treatment of C57BL/6 nude mice with anti-IL2R $\beta$ $\mathrm{mAb}$, previously reported to efficiently deplete $\mathrm{NK} 1.1^{+}$cells in vivo for at least 5 weeks, ${ }^{17,18}$ abrogated $\operatorname{IgM}$ xenoantibody production following hamster RBC immunization (MFI $16.9 \pm 3.1$ $[n=9]$ versus $48.9 \pm 6.4[n=3]$; Figure $4 A, B)$. Furthermore, transfer to BALB/c nude recipients of purified C57BL/6 NK1.1 ${ }^{+}$ but not NK1.1- splenocytes 1 week before xenografting resulted in acute vascular rejection in 4 out of 6 recipients (Table 2; groups $\mathrm{G}, \mathrm{H})$, severe inflammatory lesions in the remaining 2, and markedly increased IgM xenoantibody serum levels in all (Figure 4C). Taken together, these data indicate that in order to produce IgM xenoantibody, MZB cells require critical help from NK1.1 ${ }^{+}$cells, and that this help signal is lacking in $\mathrm{BALB} / \mathrm{c}$ nude mice.

Electron microscopic examination showed the presence of numerous large granular lymphocytes (LGLs) in the splenic white pulp of lethally irradiated C57BL/6 but not BALB/c nude mice (Figure 4D,E), and also in spleens of lethally irradiated BALB/c nude mice that rejected xenografts after having received either a 
C57BL/6 nude splenic tissue transplant (Figure 4F) or MACSpurified C57BL/6 nude NK $1.1^{+}$cells (Figure 4G). These data support the hypothesis that the identity of the radioresistant helper cell, which is able to restore the capacity of xenograft rejection and T-cell-independent IgM xenoantibody production in BALB/c nude mice in the previously mentioned splenic tissue transplantation and cell-transfer experiments (Table 2), is an NK cell.

The sole involvement of NKT cells was subsequently ruled out on the basis of 2 observations. First, 8 of $10 \mathrm{C} 57 \mathrm{BL} / 6 \mathrm{TCR} \beta^{-1-}$ recipients given a hamster heart graft rejected their xenograft after 5 to 7 days (Table 2; group J), with significantly higher IgM xenoantibody (Xab) levels on the day of rejection (mean MFI \pm SE $24.8 \pm 3.5$ versus $3.1 \pm 1.7$ in naive) and histopathologic signs typical of acute vascular rejection (not shown). Second, 3 of $4 \mathrm{BALB} / \mathrm{c}$ nude mice, given C57BL/6 $\mathrm{TCR} \beta^{-1-}$ spleen cells prior to hamster heart grafting, acutely rejected the xenografts on day 6 or 7 (Table 2; group K).

In the following control experiments, we demonstrated that following adoptive transfer in $\mathrm{BALB} / \mathrm{c}$ nude mice, at least a fraction of C57BL/6 NK cells migrated to the spleen and survived locally until the day of xenografting. This was further supported by the in vitro observations that $\mathrm{BALB} / \mathrm{c}$ nude $\mathrm{NK}$ cells fail to kill C57BL/6 target cells, and that the rapidly induced IgM xenoantibodies do not cross-react with allogeneic C57BL/6 target cells.

Flow cytometric analysis of spleens of BALB/c nude hosts that rejected xenoheart grafts after adoptive transfer of C57BL/6 $\mathrm{TCR}^{-/-}$spleen cells (Table 2; group $\mathrm{K}$ ) revealed, at the time of rejection, a clearly definable $\mathrm{H} 2 \mathrm{~Kb}^{+} \mathrm{DX} 5^{+}$cell population (establishing $3.3 \%, 1.5 \%, 2.8 \%$, and $1.7 \%$ of total spleen cells; not shown). This was confirmed in a second experiment: B-celldepleted spleen cells (obtained by CD19- MACS) from C57BL/6 $\mathrm{TCR}^{-1-}$ mice (containing $20 \% \mathrm{DX}^{+}$cells) were transferred to
BALB/c nude mice $(n=2)$ at a dose of either $32 \times 10^{6}$ or $5 \times 10^{6}$ $\mathrm{CD}_{1} 9^{-} \mathrm{TCR}^{-1-}$ spleen cells. As can be seen in Figure S3, on day 7 after adoptive transfer, the C57BL/6 NK cells, identifiable as the $\mathrm{NK} 1.1^{+} \mathrm{DX} 5^{+}$or $\mathrm{H} 2 \mathrm{~Kb}^{+} \mathrm{DX} 5^{+}$cell population, could be clearly identified in both reconstituted BALB/c nude mice, as well as in the $\mathrm{TCR} \beta^{-1-}$ naive control, but not in the naive $\mathrm{BALB} / \mathrm{c}$ nude control.

In addition, we performed NK cytotoxicity assays using BALB/c nude DX5 ${ }^{+} \mathrm{NK}$ cells as effector cells and C57BL/6 blast cells as target cells and demonstrated that BALB/c nude NK cells fail to elicit anti-C57BL/6 alloreactive cytotoxicity. A total of 2 independent experiments were performed, with identical results (Table S2).

Finally, we showed, using a sensitive flow cytometric assay, that circulating IgM xenoantibodies (obtained from BALB/c nude mice that rejected a hamster heart following adoptive transfer of C57BL/6 NK cells) do not cross-react with C57BL/6 cells (results not shown).

\section{NK1.1+-cell help requires neither NK1.1+-cell mediated IFN- $\gamma$ production nor NK-cell-mediated killing of xenotargets; the IgM xenoantibody response involves CD40-CD40L interaction}

Hamster heart transplantation in $\mathrm{BALB} / \mathrm{c}$ nude recipients given C57BL/6 IFN- $\gamma^{-1-} \mathrm{NK} 1.1^{+}$cells still led to acute vascular rejection in 3 of 4 mice (Table 2; group I), and severe inflammatory lesions in the remaining mouse.

Lack of Ly49D expression in BALB/c mice has previously been reported to account for their inability to lyse xenogeneic Chinese hamster ovary cells. ${ }^{25}$ After confirming that BALB/c nude NK cells do not express Ly49D (not shown) and exhibit defective lysis of golden hamster target cells, we used blocking anti-Ly49D antibodies to show that lysis of golden hamster target cells, and not of Yac-1 tumor cells, by C57BL/6 nude NK cells is critically
Figure 4. NK1.1 ${ }^{+}$-cell help is required for IgM xenoantibody production by MZB cells, and is deficient in BALB/c nude mice. (A-C) Hamster RBC immunization was performed in naive or TM- $\beta 1$-treated C57BL/6 nude mice. Serum IgM xenoantibody levels were measured on day 7 after immunization. (A) Bars represent means $( \pm \mathrm{SE}) \mathrm{MFI}$ of 3 naive and $9 \mathrm{TM}-\beta 1$-treated mice ( $P<.05$ for comparison between groups). (B) Histogram illustrates the MFI of 1 representative animal of both groups. (C) At 1 week before hamster heart xenografting, $6 \times 10^{6} \mathrm{NK} 1.1^{+}$or NK1.1- ${ }^{-}$cells from C57BL/6 nude naive mice were transferred to $B A L B / c$ nude naive recipients (Table 2; groups $\mathrm{G}, \mathrm{H}$ ). Serum IgM xenoantibody levels were measured at the time of graft rejection, or at day 7 . Histograms illustrate 1 representative sample of both groups. (D-H) Electron microscopy of spleen tissue from (D) a lethally irradiated C57BL/6 nude mouse, (E) a lethally irradiated BALB/c nude mouse, (F) a $\mathrm{BALB} / \mathrm{c}$ nude mouse first given transplants of C57BL/6 nude splenic tissue under the kidney capsule, subsequently given a hamster heart xenograft, and-when in the process of rejecting the xenograft-exposed to a lethal irradiation dose, and (G) a BALB/c nude mouse that first received NK1.1 $1^{+}$cells from C57BL/6 nude naive mice, subsequently was given a hamster heart xenograft and finally given lethal irradiation. All pictures were taken at the same original magnification $(\times 11000)$. Arrows indicate radioresistant large granular lymphocytes in the white pulp in panels $\mathrm{D}, \mathrm{F}$, and $\mathrm{G}$, and these cells are absent in panel E. (H) Detail of a large granular lymphocyte from the same spleen shown in panel $G$ and reveals the dense cytoplasmic granules $(\leftarrow$; original magnification, $\times 19000)$. Spleen samples used for electron microscopic examination were taken at 5 days after lethal irradiation. See "Light microscopy, immunohistochemistry, and electron microscopy" for complete image acquisition information.
A

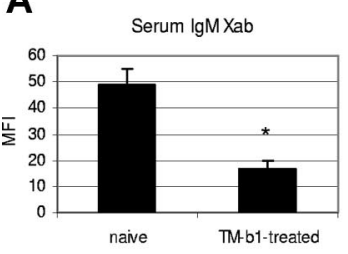

B
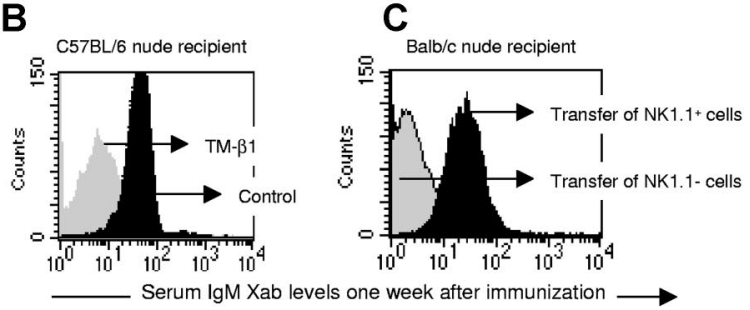

D

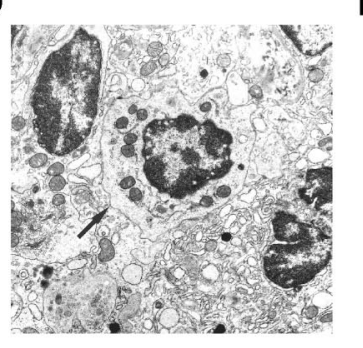

E

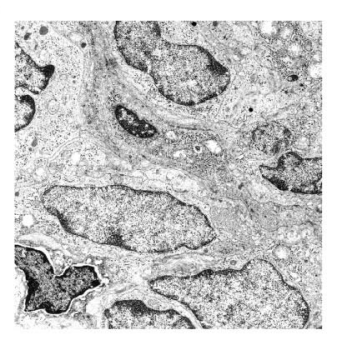

F

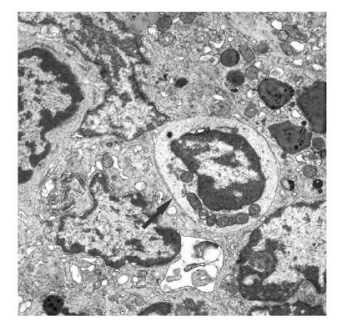

G

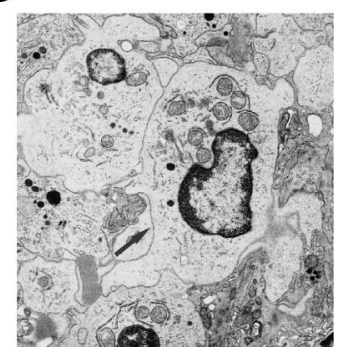

H

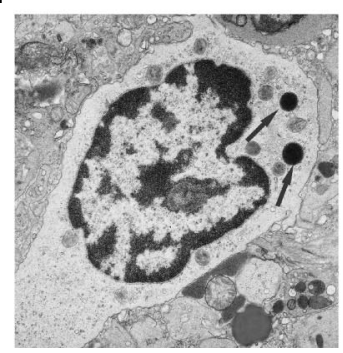


dependent on activation of Ly49D (Figure S4). However, in vivo treatment with anti-Ly49D antibodies, despite producing full in vivo blockade of splenic NK Ly49D receptors and despite abrogating the ability to lyse golden hamster target cells ex vivo, failed to interfere with the $\operatorname{IgM}$ xenoantibody response upon immunization with hamster RBCs $(n=2$; Figure $\mathrm{S} 4)$, or xenografting $(\mathrm{n}=1$; acute vascular rejection on day 7). Hence, NK-mediated lysis of T-cell-independent xenoantigen-expressing target cells is not involved in the $\mathrm{NK} 1.1^{+}$-MZB cell interaction during the T-cellindependent $\operatorname{IgM}$ xenoantibody response.

C57BL/6 nude mice were treated with MR1 $(n=6)$ or control $\operatorname{Ig}(n=6)$ from day -1 to day 5 relative to the day of hamster RBC immunization, and the level of serum IgM xenoantibody were determined on day 7. In vivo CD40L blockade was associated with significantly lower serum IgM xenoantibody levels (MFI $17.6 \pm 3.2$ $\mathrm{SE}[\mathrm{n}=6]$ in MR1-treated versus $28.1 \pm 4.2 \mathrm{SE}$ in coIg-treated $[\mathrm{n}=6] ; P<.05$; not shown), indicating that the MZB-cellmediated $\operatorname{IgM}$ xenoantibody response is-at least in partdependent on CD40-CD40L interaction.

\section{MZB cells and NK1.1+-cell help are only partially responsible} for the TNP-Ficoll IgM response

The difference in IgM xenoantibody response between C57BL/6 and $\mathrm{BALB} / \mathrm{c}$ nude mice was compared with the $\operatorname{IgM}$ response to TNP-Ficoll, a prototypical T-cell-independent type II antigen (Figures 5A, S5). In contrast to C57BL/6 nude mice, which produced high anti-TNP-Ficoll IgM levels (MFI 93.8 $\pm 9.9[\mathrm{n}=6]$ versus $26 \pm 5.2$ in naive $[\mathrm{n}=6]), \mathrm{BALB} / \mathrm{c}$ nude mice exhibited a less pronounced, but significant, response (MFI $52.5 \pm 7.6[\mathrm{n}=6]$ versus $20.8 \pm 12.8$ in naive $[\mathrm{n}=6]$ ), which was similar to that of splenectomized C57BL/6 nude mice (MFI $42.9 \pm 6.7 ; \mathrm{n}=6$ ). As expected, IgG2a formation was essentially absent in all mice, confirming the T-cell-deficient setting of the experiments. MZBcell-depleted C57BL/6 nude mice, given 2 Gy TBI on day -14 , exhibited significantly lower anti-TNP-Ficoll IgM serum levels than nonirradiated immunized controls (MFI $321 \pm 38$ versus $704 \pm 108$, respectively; Figure 5B). Transfer of C57BL/6 nude $\mathrm{NK} 1.1^{+}$cells enabled BALB/c nude mice to produce significantly higher TNP-Ficoll IgM levels (MFI $550 \pm 34$ ) than NK1.1 ${ }^{-}$-celltransferred (MFI $347 \pm 50)$ and nontransferred controls (413 \pm 24 ; Figure 5C). These data indicate that an important part of the TNP-Ficoll IgM response is mediated by MZB cells, and that this part is also dependent on NK1.1+ cells.

\section{Discussion}

Our study shows that T-cell-independent xenoantibody production to non-Gal xenoantigens in a concordant hamster-mouse combination exclusively depends on radiosensitive MZB cells, and, hence, that it differs from the T-cell-independent xenoantibody response to the Gal antigen, which was recently shown by Ohdan et al to be mediated by 3-Gy TBI-resistant Mac1- B1b-like splenic B lymphocytes. 15,26,27

Our findings may be relevant to the recently reported successful results in a preclinical xenograft model by Yamada et al ${ }^{13}$ In this study, in addition to a T-cell xenotolerance-inducing regimenconsisting of host thymectomy and xenothymus graftingrecipient baboons underwent splenectomy and were given treatment with CD40L-blocking antibodies. Based on our present study and our previous work, indicating that xenothymus grafting is insufficient to induce T-cell-independent xenotolerance, ${ }^{28}$ we hy-
A
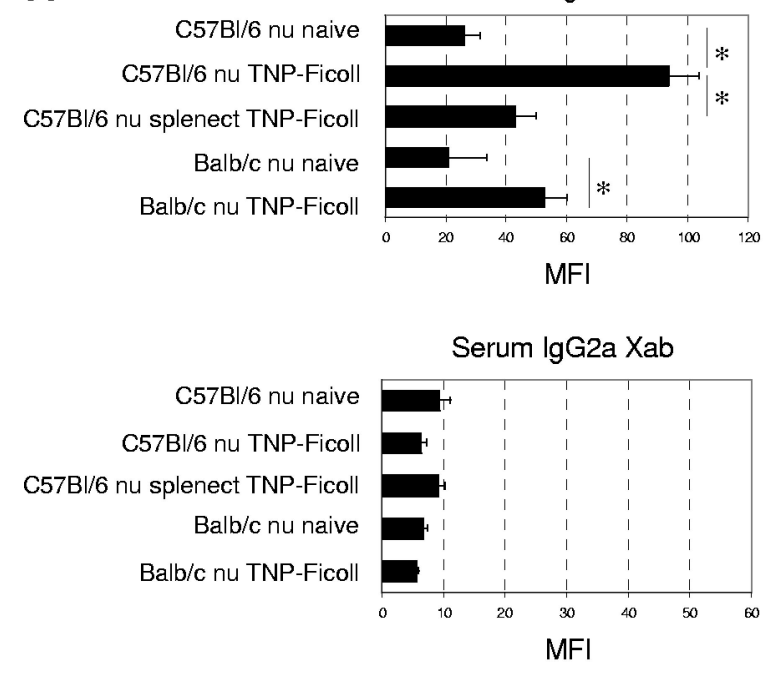

B

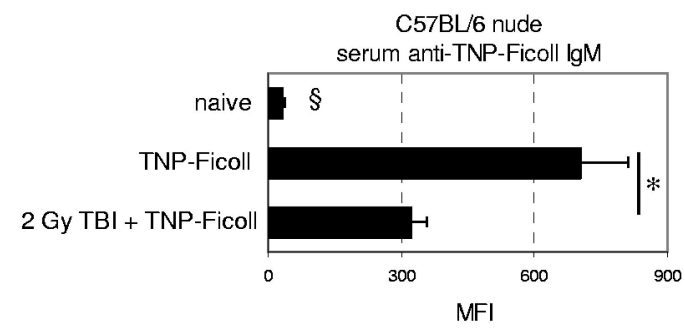

C

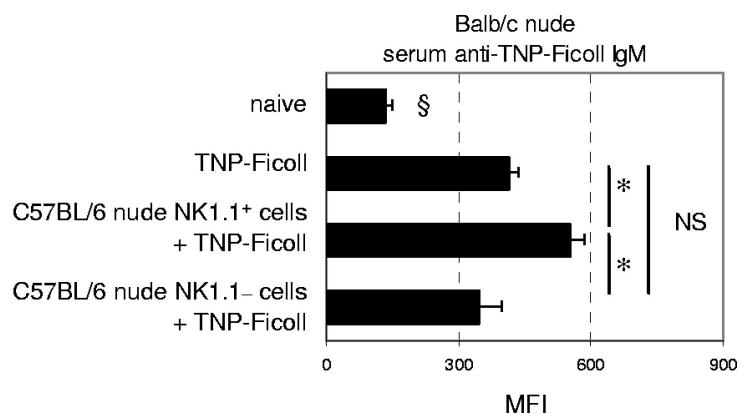

Figure 5. MZB cells and NK1.1+-cell help are only partially responsible for the TNP-Ficoll IgM response (A) On day 7 after TNP-Ficoll immunization of naive or splenectomized mice, serum was obtained for flow cytometric analysis of TNP-Ficollspecific IgM and IgG2a levels. Bars represent the mean ( \pm SE) MFI values of groups of 6 animals each. ${ }^{*} P<.05$ for comparison between groups. (B) TNP-Ficoll immunization was performed in naive or 2-Gy-irradiated C57BL/6 nude mice. Serum TNP-Ficoll IgM levels were measured on day 7 after immunization. Bars represent means ( $\pm \mathrm{SE}$ ) MFI of 4 naive nonimmunized, 5 naive immunized, and 6 irradiated immunized mice. ${ }^{*} P<.05$ for comparison between groups; $\S P<.05$ for comparison with all other groups. (C) At 1 week before TNP-Ficoll immunization, $6 \times 10^{6} \mathrm{NK} 1.1^{+}$ or NK1.1- cells ( $n=4$ per group) from C57BL/6 nude naive mice were transferred to $\mathrm{BALB} / \mathrm{c}$ nude naive recipients. Serum TNP-Ficoll IgM levels were measured on day 7 after immunization and compared with those of immunized and control BALB/c nude mice $\left(n=3\right.$ per group). Bars represent means $( \pm S E)$ MFI of each group. ${ }^{*} P<.05$ for comparison between groups; $\S P<.05$ for comparison with all other groups.

pothesize that the success of the treatment regimen by Yamada et al may be attributed in part also to effects on T-cell-independent xenoantibody production. This is further supported by the observation that in recipient baboons showing long-term graft survival, flow cytometric studies of peripheral blood lymphocytes and immunohistochemistry of tissues failed to document the presence of IgM xenoantibody. ${ }^{13}$

Our findings also reveal a novel role of NK cells for in vivo IgM xenoantibody formation. An exclusive role for NKT cells was definitively ruled out. Although NK cells have previously 
been shown to play a key role in in vitro T-cell-independent type II antibody production, ${ }^{29,30}$ contradicting evidence exists on their in vivo role. ${ }^{31-35}$ As NK1.1 ${ }^{+}$cells were critical for the entire $\operatorname{IgM}$ xenoantibody response, but only in part for the anti-TNP-Ficoll antibody response, it seems that the reported discrepancies on the role of NK cells may be due to the type of T-cell-independent antigen studied.

The precise mechanisms involved in NK-cell-mediated help for MZB cells are incompletely understood. NK-mediated IFN- $\gamma$ production, previously described as playing a role in T-cellindependent type II Ig responses, ${ }^{29,30,35}$ was not involved in our model, nor was NK-cell killing of xenoantigen-expressing targets. ${ }^{25}$ However, the MZB-cell-mediated IgM xenoantibody response was-at least in part-dependent on CD40-CD40L signaling. Human and rat NK cells can express CD40L, and it has been shown that NK-cell CD40L cross-linking leads to their activation. ${ }^{36,37}$ In addition, Blanca et al have demonstrated that CD40CD40L interaction regulates activation of human B cells by autologous NK cells. ${ }^{38}$ Although in vitro studies with murine cells have demonstrated that murine macrophages can activate NK cells through a CD40-CD40L-dependent mechanism, ${ }^{39,40}$ direct evidence of expression of CD40L by murine NK cells is- to our knowledge - as yet unavailable. Similar to what has previously been reported by Martin-Fontecha et $\mathrm{al},{ }^{41}$ we failed to detect CD40L expression in NK cells of C57BL/6 mice: neither by flow cytometry nor by reverse transcription-polymerase chain reaction (RT-PCR) could we document CD40L expression in resting NK cells or NK cells stimulated by IL-2, hamster blasts, or Yac-1 tumor cells (results not shown). Possibly, CD40L expression by murine NK cells is difficult to induce in vitro. In addition, flow cytometric detection of expression of CD40L protein, such as on T cells, is known to be technically challenging. ${ }^{42,43}$ Nevertheless, our observations are in concert with those by $\mathrm{Wu}$ et al, who showed that the in vivo T-cell-independent Ig response to phosphorylcholine in C57BL/6 mice also involves a T-cell-independent CD40L signal. ${ }^{44}$ The source of the CD40L signal and the nature of the NK-cell help signal in our model are the subject of ongoing studies. In this respect, Turner et al have shown in mice that CD40-dependent stimulation of antigen-presenting cells (APCs) can give rise to IL-12 production and subsequent NK cell activation, ${ }^{45}$ suggesting the existence of a NK-cell-independent CD40-CD40L pathway that can lead to $\mathrm{NK}$ cell activation. Likewise, $\mathrm{Wu}$ et al suggested the involvement of mast cells and auto- or paracrine B-cell signals as a source of CD40L help in the phosphorylcholine Ig response. ${ }^{44}$

In preliminary experiments, we showed that plasma cells (identified by expression of syndecan 1), CD21/CD $35^{+}$cells (Figure S6), and $\mathrm{IgM}^{+}$cells (not shown) accumulated in the splenic white pulp of C57BL/6 nude mice at the time of xenograft rejection. In addition, $\mathrm{DX} 5^{+}$cells, which in naive $\mathrm{C} 57 \mathrm{BL} / 6$ and $\mathrm{BALB} / \mathrm{c}$ nude mice is located in the red pulp, could be found in the splenic white pulp of only C57BL/6 and not BALB/c nude mice after xenoheart transplantation (Figure S6). These findings suggest that MZB-cell and NK-cell interaction in the splenic white pulp is crucial for T-cell-independent $\operatorname{IgM}$ xenoantibody production, and that a defect in the migratory capacity of BALB/c nude NK cells may underlie their inability to produce T-cell-independent IgM xenoantibodies. In this respect, it has indeed been shown that the splenic periarteriolar lymphoid sheath is the principal site where T-cell-dependent and T-cell-independent humoral immune responses take effect, ${ }^{46-48}$ and also that NK cells can migrate from the red to the white pulp. ${ }^{49}$
The mechanism underlying long-term tolerance to xenografts in 2-Gy-irradiated mice is the subject of ongoing studies. Preliminary observations in such animals, several weeks after the recovery of MZB cells, show that low levels of circulating IgM xenoantibodies can be detected, and that long-term surviving xenografts exhibit weak immunoreactivity for IgM with an absence of signs of acute vascular rejection. These data suggest that, following recovery of MZB cells, IgM xenoantibody production occurs to some extent, and that continued graft survival at this point can be attributed to graft accommodation.

If MZB cells and NK cells are so important for T-cellindependent xenoantibody production, would depletion of MZB cells (eg, by splenectomy) or precluding NK1.1+-cell- and/or CD40L-dependent help entirely solve the T-cell-independent xenoantibody problem? Our comparative studies in C57BL/6 and $\mathrm{BALB} / \mathrm{c}$ nude mice of the Ig response against the prototypical T-cell-independent type II antigen TNP-Ficoll suggest that this will probably not be the case. Indeed, only a part of the anti-TNP-Ficoll antibody response exhibited the characteristics of the antihamster xenoantibody response. In addition, it was neither completely absent in BALB/c nude mice, nor could it be completely abrogated in splenectomized or 2-Gy TBI-treated C57BL/6 nude mice, confirming earlier observations in Pyk-2deficient mice, which have deficient MZB cells but still showed a significant-albeit strongly reduced-TNP-Ficoll IgM response. ${ }^{50}$ Although it is certain that multiple T-cell-independent non-Gal xenoantigens exist, their nature and contribution to xenoreactivity in different xenogeneic species combinations have as yet not been elucidated. ${ }^{14,21,51}$ Therefore, a fraction of the T-cell-independent xenoantibody response in the pig-toprimate model may resemble the murine TNP-Ficoll Ig response, and hence would be only partially controlled by splenectomy or CD40L blockade. It will be interesting to investigate whether this is the case, for example, for some endothelial xenoantigens in porcine small arteries, and whether xenoantibodies directed against these xenoantigens are involved in the process of thrombotic microangiopathy that was seen in most of the xenografts in the study by Yamada et al. ${ }^{13}$

Full immune xenotolerance involving both the T-celldependent and T-cell-independent compartments will probably be a requirement for xenotransplantation to be safely introduced into the clinic. Induction of mixed xenogeneic bone marrow chimerism has been shown to induce robust T-cell-dependent and T-cell-independent xenotolerance in several small animal models, ${ }^{27,52-55}$ but in large animals still faces problems such as growth factor incompatibility. ${ }^{56,57}$ Xenogeneic thymus transplantation has been shown to effectively and safely induce T-cell xenotolerance. ${ }^{13,58-60}$ Ideally, this approach should be combined with a procedure leading also to T-cell-independent xenotolerance. It is hoped that our present study, elucidating some of the cell populations and mechanisms involved in T-cell-independent xenoantibody formation, may contribute to this aim and as such also to the clinical applicability of xenotransplantation.

\section{Acknowledgments}

This work was supported by a grant from the Fund for Scientific Research (FWO) Flanders. A.D.B. is a postdoctoral fellow of the FWO Flanders.

We thankfully acknowledge the assistance of Willy Landuyt (Laboratory of Oncology and Experimental Radiotherapy) in 
irradiation experiments, and of Vic Van Duppen (Stem Cell Institute Leuven) in cell sorting procedures. We thank Patrick Matthys (Laboratory of Immunobiology, Rega-institute for Medical Research), and Xavier Bossuyt (Laboratory of Experimental Laboratory Medicine, Department of Molecular Cell Biology) for scientific discussions.

\section{Authorship}

Contribution: S.L. and Y.Y. designed and performed all experiments, assisted in some cases by Y.L. or D.M.B. O.R. and J.G. provided technical assistance. C.S. was responsible for animal care.
L.B. and A.K. provided antibodies and contributed to experimental design. C.D.-P. supervised pathologic and immunohistochemical studies. R.D.V. performed electron microscopy studies. All authors contributed to data interpretation. A.D.B. and M.W. designed the study and wrote the manuscript.

S.L. and Y.Y. contributed equally to this study; M.W. and A.D.B. contributed equally to this study.

Conflict-of-interest disclosure: The authors declare no competing financial interests.

Correspondence: Mark Waer, Laboratory of Experimental Transplantation, University of Leuven, Campus Gasthuisberg, O\&N 1 Box 811, Herestraat 49, B-3000 Leuven, Belgium; e-mail: mark.waer@gbiomed.kuleuven.be.

\section{References}

1. Dorling A. Clinical xenotransplantation: pigs might fly? Am J Transplant. 2002;2:695-700.

2. Good AH, Cooper DK, Malcolm AJ, et al. Identification of carbohydrate structures that bind human antiporcine antibodies: implications for discordant xenografting in humans. Transplant Proc. 1992; 24:559-562.

3. Sandrin MS, Vaughan HA, Dabkowski PL, McKenzie IF. Anti-pig IgM antibodies in human serum react predominantly with $\mathrm{Gal}($ alpha $1-3) \mathrm{Ga}$ epitopes. Proc Natl Acad Sci U S A. 1993;90: 11391-11395.

4. Galili U, Clark MR, Shohet SB, Buehler J, Macher $\mathrm{BA}$. Evolutionary relationship between the natural anti-Gal antibody and the Gal alpha 1-3Gal epitope in primates. Proc Natl Acad Sci U S A. 1987;84:1369-1373.

5. Schuurman HJ, Cheng J, Lam T. Pathology of xenograft rejection: a commentary. Xenotransplantation. 2003;10:293-299.

6. Watts A, Foley A, Awwad M, et al. Plasma perfusion by apheresis through a Gal immunoaffinity column successfully depletes anti-Gal antibody: experience with 320 aphereses in baboons. Xenotransplantation. 2000;7:181-185.

7. Kozlowski T, lerino FL, Lambrigts $D$, et al. Depletion of anti-Gal(alpha)1-3Gal antibody in baboons by specific alpha-Gal immunoaffinity columns. Xenotransplantation. 1998;5:122-131.

8. Cozzi E, White DJ. The generation of transgenic pigs as potential organ donors for humans. Nat Med. 1995;1:964-966.

9. Lai L, Kolber-Simonds D, Park KW, et al. Production of alpha-1,3-galactosyltransferase knockout pigs by nuclear transfer cloning. Science. 2002; 295:1089-1092.

10. Phelps CJ, Koike C, Vaught TD, et al. Production of alpha 1,3-galactosyltransferase-deficient pigs. Science. 2003;299:411-414

11. Gollackner B, Goh SK, Qawi I, et al. Acute vascular rejection of xenografts: roles of natural and elicited xenoreactive antibodies in activation of vascular endothelial cells and induction of procoagulant activity. Transplantation. 2004;77:17351741.

12. Kuwaki K, Tseng YL, Dor FJ, et al. Heart transplantation in baboons using alpha1,3-galactosyltransferase gene-knockout pigs as donors: initial experience. Nat Med. 2005;11:29-31.

13. Yamada K, Yazawa K, Shimizu A, et al. Marked prolongation of porcine renal xenograft survival in baboons through the use of alpha1,3-galactosyltransferase gene-knockout donors and the cotransplantation of vascularized thymic tissue. Nat Med. 2005;11:32-34.

14. Chen G, Qian H, Starzl T, et al. Acute rejection is associated with antibodies to non-Gal antigens in baboons using Gal-knockout pig kidneys. Nat Med. 2005;11:1295-1298.

15. Ohdan H, Swenson KG, Kruger Gray HS, et al.
Mac-1-negative B-1b phenotype of natural antibody-producing cells, including those responding to $\mathrm{Gal}$ alpha 1,3Gal epitopes in alpha 1,3-galactosyltransferase-deficient mice. J Immunol. 2000; 165:5518-5529.

16. Yan $Y$, Verbeken E, Yu L, et al. Effects of a short course of leflunomide on T-independent B-lymphocyte xenoreactivity and on susceptibility of xenografts to acute or chronic rejection. Transplantation. 2005;79:135-141.

17. Tanaka T, Kitamura F, Nagasaka Y, et al. Selective long-term elimination of natural killer cells in vivo by an anti-interleukin 2 receptor beta chain monoclonal antibody in mice. J Exp Med. 1993; 178:1103-1107.

18. Kerre TC, De Smet G, De Smedt M, et al. Adapted NOD/SCID model supports development of phenotypically and functionally mature $T$ cells from human umbilical cord blood CD34(+) cells. Blood. 2002;99:1620-1626.

19. Shimizu I, Kawahara T, Haspot F, et al. B-cell extrinsic CR1/CR2 promotes natural antibody production and tolerance induction of anti-alphaGAL-producing B-1 cells. Blood. 2007;109:17731781.

20. Xia G, Ji P, Rutgeerts O, Waer M. Maintenance and reversibility of natural killer cell- and T cellindependent B lymphocyte xenotolerance in athymic nude rats. Transplantation. 1999;68:11811188 .

21. Cooper DK. Xenoantigens and xenoantibodies. Xenotransplantation. 1998;5:6-17.

22. Martin F, Oliver AM, Kearney JF. Marginal zone and $\mathrm{B} 1 \mathrm{~B}$ cells unite in the early response against T-independent blood-borne particulate antigens. Immunity. 2001;14:617-629.

23. Riggs JE, Lussier AM, Lee SK, Appel MC, Woodland $\mathrm{RT}$. Differential radiosensitivity among $\mathrm{B}$ cell subpopulations. J Immunol. 1988;141:17991807.

24. Lee SK, Woodland RT. Selective effect of irradiation on responses to thymus-independent antigen. J Immunol. 1985;134:761-764.

25. Idris $\mathrm{AH}$, Smith $\mathrm{HR}$, Mason $\mathrm{LH}$, et al. The natural killer gene complex genetic locus Chok encodes Ly-49D, a target recognition receptor that activates natural killing. Proc Natl Acad Sci U S A. 1999:96:6330-6335.

26. Kawahara T, Ohdan H, Zhao G, Yang YG, Sykes $M$. Peritoneal cavity $B$ cells are precursors of splenic IgM natural antibody-producing cells. J Immunol. 2003;171:5406-5414.

27. Ohdan H, Yang YG, Shimizu A, Swenson KG Sykes M. Mixed chimerism induced without letha conditioning prevents T cell- and anti-Gal alpha 1,3Gal-mediated graft rejection. J Clin Invest. 1999;104:281-290.

28. Xia G, Goebels J, Rutgeerts O, Vandeputte M, Waer M. Transplantation tolerance and autoimmunity after xenogeneic thymus transplantation. J Immunol. 2001:166:1843-1854.
29. Snapper CM, Yamaguchi H, Moorman MA, Mond JJ. An in vitro model for T cell-independent induction of humoral immunity: a requirement for NK cells. J Immunol. 1994;152:4884-4892.

30. Vos Q, Snapper CM, Mond JJ. Heterogeneity in the ability of cytotoxic murine NK cell clones to enhance Ig secretion in vitro. Int Immunol. 1999; 11:159-168.

31. Wilder JA, Koh CY, Yuan D. The role of NK cells during in vivo antigen-specific antibody responses. J Immunol. 1996;156:146-152.

32. Koh CY, Yuan D. The effect of NK cell activation by tumor cells on antigen-specific antibody responses. J Immunol. 1997;159:4745-4752.

33. Khater M, Macai J, Genyea C, Kaplan J. Natural killer cell regulation of age-related and type-specific variations in antibody responses to pneumo coccal polysaccharides. J Exp Med. 1986;164: 1505-1515.

34. Kim S, lizuka K, Aguila HL, Weissman IL, Yokoyama WM. In vivo natural killer cell activities revealed by natural killer cell-deficient mice. Proc Natl Acad Sci U S A. 2000;97:27312736 .

35. Szomolanyi-Tsuda E, Brien JD, Dorgan JE, et al Antiviral T-cell-independent type 2 antibody responses induced in vivo in the absence of $\mathrm{T}$ and NK cells. Virology. 2001;280:160-168.

36. Carbone E, Ruggiero G, Terrazzano G, et al. A new mechanism of NK cell cytotoxicity activation: the CD40-CD40 ligand interaction. J Exp Med. 1997;185:2053-2060.

37. Jyothi MD, Khar A. Regulation of CD40L expression on natural killer cells by interleukin-12 and interferon gamma: its role in the elicitation of an effective antitumor immune response. Cancer Immunol Immunother. 2000;49:563572.

38. Blanca IR, Bere EW, Young HA, Ortaldo JR. Human $B$ cell activation by autologous NK cells is regulated by CD40-CD40 ligand interaction: role of memory B cells and CD5+ B cells. J Immunol. 2001;167:6132-6139.

39. Scott MJ, Hoth JJ, Stagner MK, et al. CD40CD154 interactions between macrophages and natural killer cells during sepsis are critical for macrophage activation and are not interferon gamma dependent. Clin Exp Immunol. 2004;137: 469-477.

40. Atochina O, Harn D. LNFPIII/LeX-stimulated macrophages activate natural killer cells via CD40-CD40L interaction. Clin Diagn Lab Immunol. 2005;12:1041-1049.

41. Martin-Fontecha A, Assarsson E, Carbone E, Karre K, Ljunggren HG. Triggering of murine NK cells by CD40 and CD86 (B7-2). J Immunol. 1999;162:5910-5916.

42. Frentsch M, Arbach O, Kirchhoff D, et al. Direct access to CD4+ T cells specific for defined antigens according to CD154 expression. Nat Med. 2005; 11:1118-1124. 
43. Chattopadhyay PK, Yu J, Roederer M. A live-cell assay to detect antigen-specific CD4+ T cells with diverse cytokine profiles. Nat Med. 2005;11 1113-1117.

44. Wu ZQ, Vos $Q$, Shen $Y$, et al. In vivo polysaccharide-specific IgG isotype responses to intact Streptococcus pneumoniae are T cell dependent and require CD40- and B7-ligand interactions. J Immunol. 1999;163:659-667.

45. Turner JG, Rakhmilevich AL, Burdelya L, et al. Anti-CD40 antibody induces antitumor and antimetastatic effects: the role of NK cells. J Immunol. 2001;166:89-94.

46. Jacob J, Kelsoe G. In situ studies of the primary immune response to (4-hydroxy-3-nitrophenyl)acetyl, II: a common clonal origin for periarteriolar lymphoid sheath-associated foci and germinal centers. J Exp Med. 1992;176:679-687.

47. Cook MC, Basten A, Fazekas de St Groth B. Outer periarteriolar lymphoid sheath arrest and subsequent differentiation of both naive and tolerant immunoglobulin transgenic B cells is determined by $B$ cell receptor occupancy. J Exp Med. 1997;186:631-643.

48. Peakman MC, Maizels N. Localization of splenic B cells activated for switch recombination by in situ hybridization with Igamma1 switch transcript and Rad51 probes. J Immunol. 1998;161:4008-4015.

49. Salazar-Mather TP, Ishikawa R, Biron CA. NK cell trafficking and cytokine expression in splenic compartments after IFN induction and viral infection. J Immunol. 1996;157:3054-3064.

50. Guinamard R, Okigaki M, Schlessinger J, Ravetch JV. Absence of marginal zone B cells in Pyk-2-deficient mice defines their role in the humoral response. Nat Immunol. 2000;1:31-36

51. Chen $\mathrm{G}$, Sun $\mathrm{H}$, Yang $\mathrm{H}$, et al. The role of antinon-Gal antibodies in the development of acute humoral xenograft rejection of hDAF transgenic porcine kidneys in baboons receiving anti-Gal antibody neutralization therapy. Transplantation. 2006;81:273-283.

52. Bartholomew AM, Powelson J, Sachs DH, et al Tolerance in a concordant nonhuman primate model. Transplantation. 1999;68:1708-1716.

53. Ohdan H, Yang YG, Swenson KG, Kitamura H, Sykes M. T cell and B cell tolerance to GALalpha1, 3GAL-expressing heart xenografts is achieved in alpha1,3-galactosyltransferase-deficient mice by nonmyeloablative induction of mixed chimerism. Transplantation. 2001;71:1532-1542.

54. Abe M, Qi J, Sykes M, Yang YG. Mixed chimerism induces donor-specific T-cell tolerance across a highly disparate xenogeneic barrier. Blood. 2002;99:3823-3829.

55. Lan P, Wang L, Diouf B, et al. Induction of human T-cell tolerance to porcine xenoantigens through mixed hematopoietic chimerism. Blood. 2004; 103:3964-3969.

56. Tseng YL, Dor FJ, Kuwaki K, et al. Bone marrow transplantation from alpha1,3-galactosyltransferase gene-knockout pigs in baboons. Xenotransplantation. 2004;11:361-370.

57. Tseng YL, Sachs DH, Cooper DK. Porcine hematopoietic progenitor cell transplantation in nonhuman primates: a review of progress. Transplantation. 2005;79:1-9.

58. Yamamoto S, Lavelle JM, Vagefi PA, et al. Vascularized thymic lobe transplantation in a pig-to-baboon model: a novel strategy for xenogeneic tolerance induction and T-cell reconstitution. Transplantation. 2005;80:1783-1790.

59. Zhao Y, Swenson K, Sergio JJ, et al. Skin graft tolerance across a discordant xenogeneic barrier. Nat Med. 1996;2:1211-1216.

60. Nikolic B, Gardner JP, Scadden DT, et al. Normal development in porcine thymus grafts and specific tolerance of human T cells to porcine donor MHC. J Immunol. 1999;162:3402-3407. 